\title{
Universidade da Selva
}

A Universidade Federal de Mato Grosso, Cuiabá, está se estruturando com um pensamento objetivo, voltado para o meio ambiente, tendo merecido o epiteto de Universidade da Selva. Honroso apelido que a Universidade de Mato Grosso usa com orgulho.

O desenvolvimento e integração da Região Amazônica é um desafio aceito pelos brasileiros de hoje. Tarefa gigantesca, é um cometimento que ultrapassa as possibilidades de um só organismo, apresentando-se como um empreendimento multinstitucional exigindo que cada um cumpra o seu dever de participar.

A evoluçāo das atividades na Amazônia vem comprovando cada dia com mais eloqüência uma verdade com sabor acaciano mas muitas vezes esquecida: não se integra o que se desconhece. "CONHECER PARA INTEGRAR", a divisa do INPA, vai ganhando cada dia maior consistência.

Um apreciável esforço já se desenvolve com o objetivo de CONHECER a Amazônia. Os trabalhos do IPEAN, do Instituto Evandro Chagas, da SUDAM, o projeto RADAM, os esforços do Exército, Marinha e Aeronáutica, a preocupação do Conselho Nacional de Pesquisas transformando o INPA sonolento e desaparelhado num grande instituto operante, tudo representa esforço no sentido de descobrir a Amazônia.

Faltava a participação ativa das Universidades como centros formadores de técnicos, futuros pesquisadores e cientistas que irāo assegurar a consolidação e expansão daqueles órgãos de pesquisa cientifica e tecnológica.

A estruturação da Universidade de Mato Grosso, coerente com a sua vocação amazonica, promete começar a suprir aquela talta, constituindo-se mesmo num exemplo a ser meditado. Foi sem dúvida um passo corajoso. Romper com velhas estruturas para apresentar uma idéia nova, é ato que requer coragem e decisāo.

A tradição literário-humanística ainda é dominadora, dificultando a expansão das ciências naturais e da tecnologia. A ecologia é tratada como assunto romântico-literário sem conceder oportunidade aos que se preocupam com a interação dos componentes do ecossistema, o fluxo de energia, ciclo de nutrientes, dinâmica de populaçōes, etc.

E digna de louvor a atitude dos jovens professores de Cuiabá rompendo os grilhōes impostos por uma tradiçâo secular.

Uma Universidade na Amazônia especializada no estudo da Amazônia em termos de ciência e tecnologia é novidade a ser saudada com alegria e esperança. Inicia-se a formação de pessoal técnico para a pesquisa na Amazônia.

A Universidade da Selva merece do INPA o mais completo apoio. E o Reitor Gabriel Novis Neves, juntamente com sua equipe jovem, dinâmica e idealista, é digno da admiração e da gratidão de todos quantos trabalham na Amazônia pelo Brasil.

\section{O EDITOR}

\section{Editor Responsável: P. Almeida Machado INPA, Manaus - AM}

